Studia i materiały $\mathrm{z}$ dziedzictwa kulturowego Torunia i regionu, t. 1: STARE I NOWE DZIEDZICTWO TORUNIA,

Toruń 2013

http://dx.doi.org/10.12775/SiMzDzKTiR_T1.2013.003

Anna Błażejewska

(KHSZIK UMK, TORUŃ)

\title{
Kościół św. Jakuba w Toruniu w kontekście dyskusji nad znaczeniem patronatu krzyżackiego dla jego budowy i architektonicznej formy
}

Wraz z opublikowanym w ostatnim numerze malborskich „Studiów Zamkowych” artykułem Christofera Herrmanna „Kościoły krzyżackie (Ordenskirchen) - fakt czy mit? O relacjach między patronatem i mecenatem w średniowiecznych Prusach”1 powrócił żywo niegdyś dyskutowany problem związku między sprawowaniem przez Krzyżaków patronatu, a faktyczną funkcją i kształtem architektonicznym kościoła św. Jakuba w Nowym Mieście Toruniu. Chciałabym niniejszym artykułem włączyć się w tę dyskusję, przedstawiając kilka uwag. Problem ten - zwłaszcza wśród badaczy-mediewistów zajmujących się sztuką naszego regionu - jest dobrze znany, toteż dotychczasowe kluczowe wątki badawcze, odnoszące się do tytułowego zagadnienia, jedynie zasygnalizuję.

Większość autorów - poczynając od Conrada Steinbrechta² - dostrzegało istnienie bezpośredniego związku między sprawowaniem przez Zakon NMP patronatu a efektownym architektonicznym kształtem nowomiejskiego kościoła św. Jakuba uznając, iż powstał w wyniku inicjatywy budowlanej, podjętej przez Zakon. Steinbrecht uznał kościół za wzniesiony przez krzyżacki warsztat budowlany; w kształcie jego prezbiterium widział echo typu zamkowej kaplicy. Marian Kutzner ${ }^{3}$ wzmocnił tę tezę, widząc w budowli rodzaj „kościoła zamkowego", który mieścił zarówno skarbiec Zakonu (w zakrystii), jak i emporę - kaplicę na drugiej kondygnacji wieży. Stanowisko to zyskało aprobatę w licznych późniejszych publikacjach. Z kolei Marian Arszyński ${ }^{4}$ - prezentując bogaty materiał źródłowy, który wprawdzie

1 Christofer HERRMANN, Kościoły krzyżackie (Ordenskirchen) - fakt czy mit? O relacjach między patronatem i mecenatem w średniowiecznych Prusach, „Studia Zamkowe”, t. 4, Malbork 2012, s. 67-76.

2 Conrad STEINBRECHT, Die Baukunst des Deutschen Ritterordens in Preussen, Bd. 1: Thorn im Mittelalter, Thorn 1885, s. 30 .

3 Marian KUTZNER, Lubecki styl architektury gotyckiego kościoła św. Jakuba w Toruniu, [w:] Sztuka Torunia i Ziemi Chetmińskiej, red. J. POKLEWSKI, („Teka Komisji Historii Sztuki TNT” 7), Toruń 1986, s. 55-75, o „Zamkowym" charakterze kościoła zwł. s. 60-62.

4 Marian ARSZYŃSKI, Stosunki między zakonem krzyżackim a społeczeństwem $w$ świetle rozważań nad organizacja budowy kościołów parafialnych w Prusach, [w:] Zakon krzyżacki a społeczeństwo państwa $w$ Prusach, red. Z. H. NOWAK, („Rocznik Towarzystwa Naukowego w Toruniu” 86), Toruń 1995, s. 165-184. 
nie dotyczy bezpośrednio realizacji tego kościoła, a regulacji prawnych w odniesieniu do fundacji i budowy kościołów farnych w dojrzałym średniowieczu w Europie - stwierdził, że „z faktu posiadania przez Krzyżaków prawa patronatu jakiegoś kościoła nie można wyprowadzać wniosku o ich udziale w budowie” i wpływie na „kształt architektoniczny i charakter wystroju wnętrz”5, gdyż sąd taki nie ma oparcia w źródłach. W dalszej części artykułu sformułował stanowisko jeszcze bardziej jednoznaczne, udokumentowane późniejszymi (XV-wiecznymi) źródłami z regionu. Podkreślił, że ogromne znaczenie kościoła farnego dla średniowiecznej społeczności miejskiej powodowało zaangażowanie się jej (poprzez tzw. „fabrykę kościoła”) we wszelkie tyczące świątyni sprawy, łącznie z wpływem na kształt architektury i wystroju, niezależnie od prawa patronatu ${ }^{6}$ - ergo: formę architektoniczną kościoła świętojakubskiego uznał za zasługę nowomiejskich mieszczan. Zaproponowane przez siebie hipotezy Arszyński określił jedynie jako zarys problemu, wymagający dalszych, szczegółowszych badań ${ }^{7}$. Christofer Herrmann popierając stanowisko Arszyńskiego, uznał jednoznacznie, że „kościół św. Jakuba - tak jak wszystkie kościoły parafialne w miastach państwa zakonnego - został zaplanowany, zbudowany i sfinansowany przez mieszczan"8, a zdanie Steinbrechta i zwolenników jego tezy o bezpośrednim wpływie Zakonu na kształt architektoniczny kościoła określił jako mit. Wspomniany artykuł Herrmanna - choć jak twierdzi autor, jego zamiarem było „rozwinięcie tezy Arszyńskiego” - nie dostarczył jednak argumentów przekonujących, w tym także tych, które określił jako „Z zakresu historii sztuki”9 na tyle, by móc zakończyć dotychczasową polemikę. Rodzi to chęć ponownego rozważenia tego zagadnienia.

Jeśli chodzi o problem funkcjonowania kościoła św. Jakuba jako „kościoła zamkowego”, należy chyba nań patrzeć sceptycznie; pełnienie jednocześnie funkcji parafii i kościoła Zakonu, jak i w ogóle sens istnienia takiej „instytucji” w mieście (biorąc jeszcze pod uwagę przekazanie prawa patronatu cysterkom w roku 1345), byłby trudny do wyjaśnienia. W świetle (pośrednich co prawda) źródeł cytowanych przez Mariana Arszyńskiego ${ }^{10}$, nie ulega też wątpliwości, że ówczesnego prawa patronatu nie powinno się traktować jako faktu jednoznacznego ani z finansowaniem budowy, ani z decydowaniem o jej architektonicznym kształcie. Poświadcza to duża liczba parafii objętych patronatem krzyżackim (około 2/3

5 Marian ARSZYŃSKI, Budownictwo warowne zakonu krzyżackiego w Prusach (1230-1454), Toruń 1995, s. 169$70,182$.

6 TAMŻE, s. 181.

7 TAMŻE, s. 183.

8 HERRMANN 2012, s. 68. Autor proponuje jednocześnie, by nazwa „kościoły krzyżackie” odnosiła się do wiejskich kościołów niewielkich gmin - głównie w diecezji sambijskiej, które z racji finansowych nie mogły wystawić kościołów samodzielnie, i które finansowali i budowali Krzyżacy - por. s. 71.

9 TAMŻE, s. 68-71. Niektóre spostrzeżenia w tym artykule brzmią nawet sprzeczne. Autor stwierdza m. in., że „byłoby bardzo dziwne, gdyby wspaniałe zamki zakonu krzyżackiego nie oddziałały w żaden sposób na budowle w miastach” (wyróżn. A.B.) - w innym miejscu nieco deprecjonując osiągnięcia Zakonu w zakresie realizacji architektonicznych. Trudno też uznać za przekonujący przytaczany przez Herrmanna argument, przemawiający za odrębnością kościoła św. Jakuba od budowli „krzyżackich”, gdy np. za świadectwo tej odrębności uznaje nieobecność szkarp w elewacjach zamków krzyżackich kontrastującą z gęstym oszkarpowaniem elewacji kościoła św. Jakuba (por. TAMŻE, s. 70).

10 ARSZYŃSKI 1995, Stosunki między..., zwł. s. 169-175. 
w samej ówczesnej ziemi chełmińskiej) ${ }^{11}$, których kościoły mają różną klasę artystyczną, różne też były dzieje ich budowy. Ponadto, jeśli tuż po ukończeniu budowy lub w jej fazie końcowej Krzyżacy przekazali patronat nad parafią konwentowi żeńskiemu - jak było to w przypadku kościoła św. Jakuba - oznacza to, że samo posiadanie prawa patronatu nie miało dla nich szczególnego znaczenia. Nie rozwiewa to jednak wątpliwości, jakie rodzą się, gdy chcemy przypisać całość realizacji kościoła (wraz z koncepcją architektoniczną) społeczności nowomiejskiej. U podstaw dotychczasowego sporu leży bowiem trudna do pogodzenia sprzeczność, która zachodzi między:

1. przyjętym w ówczesnych miastach europejskich zwyczajem / prawem organizowania budowy kościoła (finanse, program architektoniczny) przez uprawnioną do tego instytucję miejską - tzw. witryków

i tym, co stwierdzić możemy naocznie:

2. budowla, o której mowa, ma szczególne walory artystyczne (il. 1-2); uchodzi za jedną z ciekawszych XIV-wiecznych realizacji sakralnych nie tylko na obszarze państwa krzyżackiego, ale w całym tzw. Backsteingebiet, co wobec powyższego, nakazywałoby umieszczać elity młodego, kupiecko-rzemieślniczego Nowego Miasta niezwykle wysoko w hierarchii zleceniodawców budowli sakralnych na obszarze całego południowego pobrzeża Bałtyku, tak pod względem wysiłku finansowego, jak i przede wszystkim - gustu artystycznego.

Na to nakłada się brak źródeł pisanych, odnoszących się bezpośrednio do budowy tego kościoła. Uważam, że szereg argumentów przemawia za tym, by mimo braku jednoznacznie brzmiących źródeł, hipotezę o czynnym udziale Zakonu czy komturstwa toruńskiego w tym budowlanym przedsięwzięciu uznać jednak za godną rozważenia. Odnoszą się one zarówno do faktów historycznych, jak i zachowanych czy znanych śladów działalności artystycznej. Cała dotychczasowa literatura przedmiotu - niezależnie od zapatrywań poszczególnych autorów na przyczyny powstawania tzw. Nowych Miast ${ }^{12}$ - jednoznacznie wypowiada się o niższym statusie tychże względem Starych Miast, obok których wyrosły. Nie inaczej jest w przypadku Nowego Miasta Torunia. U schyłku XIII wieku wymogi odnośnie do cenzusu

11 Było to argumentem dla Christofera Herrmanna, por.: HERRMANN 2012, s. 68. O zagadnieniach związanych z tworzeniem sieci parafii: Waldemar ROZYNKOWSKI, Powstanie i rozwój sieci parafialnej w diecezji chetmińskiej w czasach panowania zakonu krzyżackiego, Toruń 2000, s. 26.

12 W myśl jednej z hipotez celem zakładania „Nowych Miast” obok „Starych” było zapobieżenie nadmiernemu rozwojowi istniejącego ośrodka miejskiego, stwarzającego swoiste zagrożenie dla pana feudalnego, w myśl innej szybki wzrost ludności w gminie miejskiej, utrudniający egzystencję na wytyczonym przy lokacji obszarze. Na ten temat istnieje duża literatura przedmiotu; w odniesieniu do miast w Prusach krzyżackich por. Antoni CZACHAROWSKI, Die Gründung der „Neustädte” im Ordensland Preussen, „Hansische Geschichtsblätter”, Jg. 108, 1990, s. 1-12; TENŻE, Początki „Nowych Miast” w państwie krzyżackim [w:] Czas, przestrzeń, praca w dawnych miastach, red. A. WYROBISZ i in., Warszawa 1991, s. 47-55; Zenon Hubert NOWAK, Neustadtgründungen des Deutschen Ordens in Preussen. Entstehung, Verhältnisse zu den Altstädten, Ende der Eigenständigkeit, [w:] Stadt und Orden. Das Verhältnis des Deutschen Ordens zu den Städten in Livland, Preußen und im Deutschen Reich, Hg. U. ARNOLD, („Quellen und Studien zur Geschichte des Deutschen Ordens“, Bd. 44), Marburg 1993, s. 129-142; Janusz TANDECKI, Struktury administracyjne $i$ społeczne oraz formy życia $w$ wielkich miastach Prus Krzyżackich i Królewskich w średniowieczu i na progu czasów nowożytnych, Toruń 2001, zwł. s. 13-15. W tych publikacjach obficie cytowana starsza literatura przedmiotu. W odniesieniu do „Nowych Miast” w Europie - por. Marek SŁOŃ, Miasta podwójne i wielokrotne w średniowiecznej Europie, Wrocław 2010, zwłaszcza rozdz. IV.1: Przebieg i przyczyny lokacji nowomiejskich, s. 425-440 (tam także literatura przedmiotu). 
majątkowego od kandydatów na obywatela Nowego Miasta były niższe, niż w przypadku ubiegania się o obywatelstwo Starego Miasta Torunia; Nowe Miasto miało mniejsze wpływy z tytułu czynszów i jednocześnie większą zależność od Zakonu: jatki i dom kupiecki pozostawały w gestii Krzyżaków (co potwierdził jeszcze w 1303 roku Konrad von Sack), komtur krzyżacki zasiadał w radzie Nowego Miasta ${ }^{13}$ zapewne wpływając na jej decyzje - zakres samorządności, podobnie jak w przypadku innych miast tego rodzaju, był zatem węższy ${ }^{14}$. Krzyżacy - jako władca feudalny - zachowywali prawo do przedstawiania kandydatów (związanych z Zakonem) na stanowisko proboszcza parafii, zachowywali też wpływ na elity władzy. Sieć wielorakich zależności oraz powiązań z Zakonem i komturstwem toruńskim sprzyjała zapewne nie tylko naciskom suwerena na społeczność nowomiejską (np. w formie ograniczeń różnego typu), ale i bliskiemu współdziałaniu.

Przyjmując, że oba miasta: Stare i Nowe - rozdzielono definitywnie w roku $1276^{15}$ należy pamiętać, że u progu wieku XIV była to jeszcze młoda, formująca się gmina. Gdy podejmowano decyzję o wzniesieniu obecnego kościoła parafialnego, był to ośrodek, „w którym trudno doszukiwać się śladów patrycjatu”16, skupiający głównie sukienników, garbarzy, kuśnierzy i innych rzemieślników. Warto podkreślić, że około połowy wieku XIV (więc zapewne i wcześniej) - obywatele sprawujący władzę w Nowym Mieście byli kupcami i rzemieślnikami ${ }^{17}$.

W kontekście tych faktów trudno zrozumieć, jak owa gmina miejska, nie dysponująca nawet własnym patrycjatem ${ }^{18}$, mogła zdobyć się na tak znaczny wysiłek finansowy, a zwłaszcza na zaangażowanie wybitnego architekta, który wykazywał nie tylko świetne wyczucie możliwości, jakie daje budulec ceglany, ale i biegłą znajomość form stosowanych w architekturze kamiennej południowo-zachodnich Niemiec ${ }^{19}$. Kościół św. Jakuba zgodnie przecież

13 Rada niewątpliwie podejmowała na posiedzeniach ważką sprawę budowy świątyni.

14 Jerzy PRZERACKI, Elita rządząca Nowego Miasta Torunia do połowy XIV wieku, „Rocznik Toruński”, t. 12, 1977, s. 187-204, zwł. s. 187. Dopiero od lat 20. XIV w. w Nowym Mieście Toruniu został przyporządkowany radzie urząd sędziego - por. Roman CZAJA, Miasta pruskie a zakon krzyżacki. Studia nad stosunkami między miastem a władza terytorialna w późnym średniowieczu, Toruń 1999, s. 87.

15 Tomasz JASIŃSKI, Toruń XIII-XIV wieku - lokacja miast toruńskich i początki ich rozwoju (1231-około 1350), [w:] Historia Torunia, red. M. BISKUP, t. 1: W czasach średniowiecza (do roku 1454), Toruń 1999, rozdz. III, s. $100-166$, s. 146.

16 TANDECKI 2001, s. 72. Por. także: Krzysztof MIKULSKI, Przestrzeń i społeczeństwo Torunia od końca XIV do początku XVIII wieku, Toruń 1999, s. 38.

17 MIKULSKI 1999, s. 38. Por. także: PRZERACKI 1977.

18 Patrycjat, jako najwyższa w hierarchii miejskiej społeczność niewątpliwie zainicjował działania artystyczne określane w historii sztuki jako „sztuka miast i mieszczaństwa” w późnym średniowieczu. Zjawisko to w naszym regionie możemy zaobserwować na przykładzie ambicji patrycjatu tzw. wielkich miast pruskich, zwłaszcza rady miasta Gdańska - wznoszącej i wyposażającej „swój” kościół farny, por. Marian KUTZNER, Die spätmittelalterliche Ausstattung der Marienkirche als Ausdruck der intellektuellen Empfindsamkeit und Religiosität der Danziger Bürger im ausgehenden Mittelalter, [w:] Die sakrale Backsteinarchitektur des südlichen Ostseeraums - der theologische Aspekt, Hg. G. EIMER, E. GIERLICH, (Kunsthistorische Arbeiten der Kulturstiftung der Deutschen Vertriebenen“, Bd. 2), Berlin 2000, s. 131-155; Elżbieta PILECKA, Charakter hanzeatyckiej sztuki miast pruskich późnego średniowiecza na przykładzie sakralnej architektury Gdańska, [w:] Sztuka Prus XIII-XVIII wieku, red. M. WOŹNIAK, („Studia Borussico-Baltica Torunensia Historiae Artium”, t. 1), Toruń 1994, s. 39-70.

19 Por. KUTZNER 1986, gł. s. 72-74. W przypadku prezbiterium kościoła św. Jakuba architekt - co, jak się wydaje, niewystarczająco dotąd podkreślano - świetnie pogodził chęć nadania wnętrzu prezbiterium charakteru 
zaliczono do czołowych realizacji XIV wieku - i to nie tylko na obszarze państwa zakonne$\mathrm{go}^{20}$.

Czy możliwe jest, by ówczesne elity Nowego Miasta Torunia były w stanie określić taką koncepcję architektoniczną i podjąć wyzwanie jej realizacji? W tego rodzaju przedsięwzięciach niekwestionowana jest rola architektów/budowniczych, przygotowujących projekt budowli i kierujących jego realizacją. Niestety, do okresu sprzed połowy XIV wieku brak jest danych o budowniczych działających na terenie nie tylko Torunia, ale i Prus ${ }^{21}$. O ile wiadomo, że w późniejszym okresie budowniczowie - także do realizacji w obrębie zamków krzyżackich - powoływani byli w znacznej mierze spośród rzemieślników miejskich ${ }^{22}$, co do wcześniejszego okresu ich rodowód nie jest znany. Jeśli nawet założylibyśmy, że władze miejskie całkowicie zdały się w zakresie koncepcji na architekta/budowniczego, to już sam fakt wyboru takiego a nie innego mistrza byłby zadziwiający, gdyż potwierdzałby równie znacząco znajomość ówczesnych rozwiązań i form architektonicznych oraz ich semantyki wśród przedstawicieli kupców i rzemieślników. Wydaje się to bardzo mało prawdopodobne, jednakże mimo wszystko warto jeszcze przyjrzeć się kilku realiom, w jakich mogły zapadać ewentualne decyzje mieszczan.

1. Mieszkańcy Nowego Miasta wywodzili się głównie ze Śląska ${ }^{23}$, podobnie jak znaczna część mieszkańców Starego Miasta i zapewne tamta tradycja artystyczna była im znana; jeśli założylibyśmy ich „czynny” udział w przygotowaniu koncepcji architektonicznej kościoła czy angażowaniu architekta, zrozumiałe byłoby, gdyby w strukturze architektonicznej nowomiejskiej fary pojawiły się nawiązania do budowli śląskich - czy to w typie, czy w elementach i detalach. Formy architektoniczne kościoła św. Jakuba nie noszą jednak śladów śląskiej genezy. Jeśli już, to nielicznych wspólnych cech $\mathrm{z}$ architekturą śląską można by się doszukać np. we

trójbocznego zamknięcia, $\mathrm{z}$ takim jego rozwiązaniem od zewnątrz, które jako jedyne umożliwiło wyprowadzenie dużej, dekoracyjnej formy wschodniego szczytu. Przy zastosowaniu wielobocznego zamknięcia od zewnątrz można by co najwyżej wyprowadzić niewielkie szczyciki wieńczące poszczególne jego ściany, co dawałoby bez porównania słabszy efekt. Por. JAKUB ADAMSKI, Pseudopoligonalne sklepienie w chórze kościoła pw. św. Jakuba w Toruniu - próbanowego spojrzenia, [w:] Dzieje i skarby kościoła Świetojakubskiego w Toruniu. Materiały z IV Sesji Naukowej Toruńskiego Oddziału SHS, z cyklu Dzieje i skarby kościołów toruńskich zrealizowanej przy współpracy Biblioteki Uniwersyteckiej UMK w Toruniu, 26-28 października 2009 roku, red. K. KLUCZWAJD, Toruń 2010, s. 73-90; ADAM SOĆKO, Trzy etapy budowy chóru kościoła pw. św. Jakuba w Toruniu, [w:] TAMŻE, s. 49-72.

20 Omówienia tego kościoła obfitują w sformułowania, oddające fascynację jego klasą artystyczną, por. dla przykładu: Ernst GALL, Danzig und das Land an der Weichsel, München 1953, s. 92 - „klejnot architektury ceglanej”; Jerzy FRYCZ, Gotycka architektura Torunia, [w:] Sztuka Torunia i Ziemi Chełmińskiej, red. J. POKLEWSKI, („Teka Komisji Historii Sztuki TNT”, t. 7), Toruń 1986, s. 40: „Kościół św. Jakuba, a zwłaszcza jego chór i rozwiązanie jego ściany szczytowej jest dziełem bardzo wybitnym, wyprzedzającym późnogotyckie ozdobne szczyty kościołów mariackich w Neubrandenburgu, Greifswaldzie i Prenzlau”.

21 Por. podstawowe zestawienie i omówienie w: Bernhard SCHMID, Die Baumeister in Deutschordenslande Preußen, „Schriften der Königsberger Gelehrten Gesselschaft“, 15/16, Geisteswissenschaftliche Klasse, H. 1; Arthur SEMRAU, recenzja pracy SCHMIDA, „Mitteilungen des Coppernicus-Vereins für Wissenschaft und Kunst zu Thorn“, H. 47, 1939, s. 107-110.

22 ARSZYŃSKI 1995, Budownictwo..., s. 154-155.

23 MIKULSKI 1999, s. 40. 
wspomnianej, wznoszonej niemal równocześnie farze staromiejskiej ${ }^{24}$. W tym względzie mieszkańcy Nowego Miasta nie inspirowali się też doświadczeniami powstającego niemal równocześnie Nowego Miasta we Wrocławiu, które wyrosło około 1261 roku tuż obok Starego (lokacja w 1263 roku). Było ono pozbawione wyodrębnionego placu targowego i placu przeznaczonego na kościół parafialny ${ }^{25}$. $\mathrm{Na}$ jego obszarze znajdował się skromny kościół szpitalny św. Ducha.Poza brakiem inspiracji płynących ze Śląska zastanawia, że oprócz kilku detali czy malowanej maswerkowej dekoracji ${ }^{26}$, ani typ architektoniczny, ani zwłaszcza szczyt wschodni kościoła świętojakubskiego nie znajdują analogii choćby w toruńskich budowlach staromiejskich, w tym we wznoszonej zapewne równolegle farze.Ta zresztą, jako realizacja sakralna znacznie bogatszej, staromiejskiej gminy, miałaby prawo być „wzorem” dla Nowego Miasta, podczas gdy w rzeczywistości w sensie klasy architektonicznej była niewątpliwie budowlą mniejszej rangi (il. 2, 3).

2. Nie są nam znane inne dokonania artystyczne mieszkańców Nowego Miasta z tego czasu, poświadczające równie wysokie aspiracje artystyczne jego mieszkańców. Nie znamy pierwotnego kształtu Ratusza, który istniał być może w 1291 roku ${ }^{27}$, jednak i ten $\mathrm{z}$ drugiej połowy XIV wieku, znany z rysunków Steinera (il. 4), był o wiele skromniejszy niż ówczesny ratusz Starego Miasta. Nie mamy bliższych danych o budynkach mieszkalnych z początku XIV wieku. Zachowane malowidła ścienne - w domu przy ul. Królowej Jadwigi 9 ze scenami z Legendy św. Urszuli, św. Marcina, Pokłonem Trzech Króli, są późniejsze (ok. 1400) ${ }^{28}$ i jakością ani programem nie wyróżniają się szczególnie na tle ówczesnych malowideł ściennych Torunia czy innych miast pruskich.

3. Nie bez znaczenia wydaje się porównanie tej nowomiejskiej realizacji z kościołami parafialnymi innych „Nowych Miast” w Prusach krzyżackich. Choć Nowe Miasto Toruń było pierwszym tego typu w państwie zakonnym ${ }^{29}$ i wyprzedzało czasowo

24 Za „śląski” element w prezbiterium staromiejskiej fary mogłyby być uznane półośmioboczne, masywne lizeny, zbliżone do podobnych elementów np. w kościele św. Krzyża we Wrocławiu. Można by też ostrożnie sugerować, że w reliktach pozostałych po wieży zamku krzyżackiego sposób połączenia materiału ceglanego z kamieniem, co zastosowano w gzymsie cokołowym i narożach wieży zamkowej, wskazywałby na ewentualne śląskie wzory.

25 Por. hasło: Nowe Miasto Wrocław, [w:] Leksykon architektury Wrocławia, red. R. EYSYMONTT, J. ILKOSZ, A. TOMASZEWICZ, Wrocław 2011, s. 20. O nieistniejącym od 1597 r. kościele Ducha św. - por. hasło: kościół szpitalny św. Ducha przy moście piaskowym, [w:] Atlas architektury Wrocławia, T.1, oprac. J. HARASIMOWICZ, Wrocław 1997, s. 33.

26 Por. Elżbieta PILECKA, Kościół p.w. św. Jana Chrzciciela $i$ św. Jana Ewangelisty w Toruniu w okresie średniowiecza jako wizualizacja świadomości społecznej, [w:] Dzieje i skarby kościoła świętojańskiego w Toruniu. Materiały $z$ konferencji przygotowanej przez Toruński Oddział Stowarzyszenia Historyków Sztuki w X rocznicę ustanowienia diecezji toruńskiej 22-23 marca 2002, red. K. KLUCZWAJD, M. WOŹNIAK, Toruń 2002, s. 119-176, s. 132.

27 Eugeniusz GĄSIOROWSKI, Ratusz staromiejski w Toruniu, Toruń 2004, s. 38, powołuje się na niejasną wzmiankę u Praetoriusa.

28 Por. Jerzy DOMASŁOWSKI, hasło: Dom przy ul. Królowej Jadwigi 9(d. ul. Sadlarska), [w:] Malarstwo gotyckie $w$ Polsce, T. 1-3, red. A.S. LABUDA, K. SECOMSKA, Warszawa 2004, T.2, cz. 3: Katalog, s. 105-106. Tam też zestawienie literatury przedmiotu.

29 Por. Liliana KRANTZ-DOMASŁOWSKA, Miasta podwójne w państwie krzyżackim - przykład Torunia, RIHA Journal 0067 (8 March 2013), dostęp online: http://www.riha-journal.org/articles/2013/2013-jan-mar/krantz- 
dość znacznie następne lokacje, takie jak Nowe Miasto Królewiec (Lipnik) - założone w roku 1300, Knipawa - w roku 1327, Nowe Miasto Elbląg - w 1347 roku, Stare Miasto Gdańsk (obok starszego Prawego) w 1377, Nowe Miasto Gdańsk w $1380 \mathrm{roku}^{30}$; zapewne te następne powstawały w nieco innych realiach, jednak wydają się one materiałem możliwym do porównań. W żadnym z innych „Nowych Miast” w Prusach nie są znane równie wybitne realizacje far, a tym bardziej takie, które w sensie architektonicznego programu byłyby efektowniejsze, niż fary ich „Starych Miast”. Dobrym przykładem jest Nowe Miasto Elbląg - uchodzące za założenie „typowe” dla Prus krzyżackich pod względem powierzchni i układu ${ }^{31}$. Na jego obszarze znajdował się kościół szpitalny św. Jerzego i skromny kościół parafialny p.w. Trzech Króli (il. 5) 32. Takie porównania czynią toruńską farę nowomiejską realizacją jeszcze bardziej odosobnioną.

Przy niższym od „wielkich miast” pruskich statusie Nowego Miasta Torunia zwraca uwagę jego rozplanowanie z wpasowaniem się w ważne szlaki handlowe - co uchodzi za wyśmienity pomysł mierniczego ${ }^{33}$ oraz przesunięcie placu rynkowego $\mathrm{z}$ centrum $\mathrm{w}$ stronę zamku $(\text { il. } 6)^{34}$. W związku z tym plac pod budowę kościoła wytyczony został nietypowo, bo w zasadzie na skraju powstającego miasta, w jego północno-wschodnim narożniku, ale za to wzniesiony na nim kościół był świetnie wyeksponowany od strony głównych szlaków wiodących do miasta: $z$ Prus i od Dobrzynia; jego efektowna forma architektoniczna stanowiła aż do XIX wieku widoczną z daleka wizytówkę miasta (il. 7).

Obywatele Nowego Miasta, w większości wywodzący się z miast takich jak Świdnica, Legnica i inne, znali zapewne z bezpośrednich przekazów starszych pokoleń zasady organizacji budowy w miastach śląskich, w tym także istotną w nich rolę tamtejszego władcy księcia Henryka I Brodatego. Warsztaty pracujące dla śląskiego księcia - „książęce” (m. in. przy legnickim palatium) podejmowały także, zapewne z inicjatywy władcy, budowę np. far miejskich (przykład Złotoryi) ${ }^{35}$. Znajomość takiej praktyki u mieszkańców Nowego Miasta czyniłaby zdanie się na zaangażowanie i wsparcie przedstawicieli zakonu krzyżackiego w kwestii planowania budowy kościoła czy osoby budowniczego i warsztatu budowlanego

-domaslowska-miasta-podwojne.

30 TANDECKI 2001, s. 13. Pominęłam tu Nowe Miasto Braniewo - lokowane w 1342 r., jako że założone zostało przez biskupa warmińskiego, a nie przez Zakon.

31 Roman CZAJA, Socjotopografia miasta Elblaga w średniowieczu, Toruń 1992, s. 168.

32 Ów niewielki kościół parafialny z braku środków finansowych nie został nawet ukończony w kształcie, jaki zaplanowali mieszczanie - por. Mieczysław JÓZEFCZYK, Średniowiecze Elblaga. Z problematyki społeczno-religijnej, Elbląg 1996, s. 117, 123.

33 JASIŃSKI 1999, s. 144.

34 Por. MIKULSKI 1999, s. 38. Krzysztof Mikulski przyznaje, że silne więzy łączące miasto z zamkiem znajdowały odzwierciedlenie w elementach architektonicznych, takich jak Brama Garbarska - stanowiąca część nowomiejskich murów obronnych, a zdaniem tegoż badacza - będąca jednocześnie główną bramą wjazdową na teren zamku; por. TAMŻE, przyp. 160. Należy też pamiętać, że sprawy związane z dyspozycją planu miasta, leżały najpewniej w zakresie obowiązków suwerena.

35 Marian KUTZNER, „Na drodze ku chwale” - ideowe programy fundacji artystycznych księcia śląskiego Henryka Brodatego, [w:] Księga Jadwiżańska. Międzynarodowe Sympozjum Naukowe: Swięta Jadwiga w dziejach i kulturze Śląska, Wrocław - Trzebnica 21-23 września 1993, red. K. BOBOWSKI i in., Wrocław 1995, s. 135-150, gł. s. 140. 
bardziej zrozumiałym. Wielki rozmach budowlany, datujący się od schyłku XIII wieku w Zakonie i znaczna liczba inicjatyw artystycznych (różnorodnych także pod względem programów) pozwalał najpewniej młodej gminie miejskiej Torunia widzieć w Zakonie krzyżackim doświadczoną instytucję w zakresie sformułowania programu architektonicznego kościoła oraz wyznaczenia dla jego realizacji odpowiednich wykonawców. Wprawdzie już w pierwszej połowie XIV wieku w miastach państwa zakonnego dostrzegalny jest proces przejmowania przez rady miejskie zarządzania dochodami i wydatkami kościołów parafialnych ${ }^{36}$, ale wiele wskazuje na to, że w mniej znaczących gminach miejskich, a nawet w tzw. wielkich miastach pruskich, do których zaliczały się w XIII i początku XIV wieku: Chełmno, Stare Miasto Toruń, Stare Miasto Elbląg, Stare Miasto Braniewo, Stare Miasto Królewiec i Główne Miasto Gdańsk, dopiero w ostatniej ćwierci XIV wieku następowało odsuwanie od spraw związanych z organizowaniem budowy proboszczów-członków Zakonu, jak miało to miejsce np. w Gdańsku w trakcie wznoszenia kościoła Mariackiego ${ }^{37}$. Instytucja witryka - wchodzącego w skład rad miejskich i zarządzającego majątkiem kościoła parafialnego - wymieniana jest w źródłach dopiero po połowie XIV wieku ${ }^{38}$. Jest to też czas, w którym miasta zaczynają w istotny sposób „kształtować” charakter i wystrój swoich far ${ }^{39}$.

Należy podkreślić, że kościół parafialny Nowego Miasta Torunia różni się od kościołów innych Nowych Miast w Prusach, w których realizowano skromniejsze budowle. Nie jest więc typowym Nowym Miastem - przynajmniej, gdy chodzi o kościół parafialny. Jednak przyczyn tej odmienności trudno w kontekście powyższych uwag upatrywać w szczególnych możliwościach i ambicjach mieszczan. Może Zakon traktował to miasto jako pierwsze, wzorcowe Nowe Miasto w Prusach i z tego względu uczynił wyjątek, wspierając je efektowną realizacją kościoła? Tak więc najpewniej nie samo prawo patronatu, ale raczej splot lokalnych, indywidualnych potrzeb oraz możliwości i ambicji Zakonu mógł zaważyć na zrealizowaniu budowy kościoła dla gminy miejskiej przez Krzyżaków.

To, że istniały różnego rodzaju powiązania między realizacjami powstającymi w miastach a tymi wykonywanymi bezpośrednio na potrzeby Zakonu, zdaje się m.in. potwierdzać działalność warsztatów rzeźbiarskich pracujących zarówno dla Krzyżaków - w kaplicy zamku brodnickiego i w kościele zamkowym w Malborku - jak i dla fary chełmińskiej w latach 30. i 40. XIV wieku. Podobieństwo między dziełami dotyczy nie tylko cech stylistyczno-warsztatowych czy techniki wykonania, ale - co ważne - także programu ideowego, co może świadczyć o ściślejszym powiązaniu tych realizacji, niż tylko korzystaniu z usług tych samych warsztatów ${ }^{40}$. Porównanie posągów apostołów brodnickich i chełmińskich

36 ARSZYŃSKI 1995, Stosunki..., s. 176-177; CZAJA 1999, s. 48.

37 PILECKA 1994, zwł. s. 52.

38 CZAJA 1999, s. 48, przyp. 207.

39 TAMŻE; por. także: Pilecka 1994.

40 Por. omówienie u: Tadeusz JURKOWLANIEC, Gotycka rzeźba architektoniczna $w$ Prusach, („Studia z historii sztuki”, red. J. KOWALCZYK i inn, t. 42), Wrocław 1989, zwł. s. 76-80; TENŻE, Rzeźba architektoniczna na zamku krzyżackim w Brodnicy, „Biuletyn Historii Sztuki”, t. 41, 1979, nr 1, s. 3-20. Por. także: Juliusz RACZKOWSKI, Stan badań nad średniowiecznymi rzeźbiarskimi Kolegiami Apostolskimi w Prusach, [w:] Album Amicorum. Między Wilnem a Toruniem. Ksiega pamiątkowa dedykowana prof. Józefowi Poklewskiemu, red. E. BASIUL i in., Toruń 2008, s. 277-292 oraz TENŻE, Treści ideowe średniowiecznych zespołów Collegium Apostolorum w Prusach Krzyżackich, 
pozwala wysnuć wniosek o nieco lepszej klasie tych pierwszych. To potwierdzałoby kierunek inspiracji - „od Zakonu do miast”, a nie odwrotnie. Niewykluczone, że jakieś znaczenie dla powyższej argumentacji może mieć podobny, południowo-zachodnioniemiecki rodowód szeregu form architektonicznych kościoła św. Jakuba i styl wspomnianych kolegiów apostolskich, który choć złożony, nosi w sobie także cechy tradycji artystycznej tamtego regionu ${ }^{41}$. Jeśli by przyjąć, że te realizacje: nowomiejski kościół i wymienione zespoły rzeźby architektonicznej łączy jednak wspólny fundator - zakon krzyżacki - mogłoby to potwierdzać preferowanie w kręgach Zakonu tego niezwykle znaczącego środowiska artystycznego.

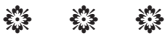

\section{St. James' church in Torun and the discussion on relevance of the Teutonic Knights' patronage for its construction and architectural form.}

This article shows the problem of taking the initiative - by the citizens or the Teutonics knights as for the artistically ambitious architectural form of St. James' Church in the New Town of Torun. The subject has been enlived recently just after the article: „The 'Teutonic Knights' churches (Ordenskirchen): fact or myth? On the interrelations between ecclesiastical and artistic patronage in medieval Prussia" by Ch. Herrmann. The author said in it critically about the influence of the Teutonic Order on the shape of St. James' Church building architecture.

From my point of view, nowadays there are some unsatisfactory explanations and controversions as to the fact how the researches interpretate the role of a young town borough. As we know, the social status of middle class people was then definitely lower than the citizens of socalled "great Prussian cities". Next, I consider how the inhabitants of medieval Torun could do it, not being financially and intellectually capable of realizing such an exceptional building in the scale of the whole Baltic area.

The comparison between St. James' Church and simplier medieval parish ones, erected in other "New Towns", in the Teutonic Order way, is supposed to be the testimony of an exceptional character of church architecture in Torun. It is seemed to be that in Torun as the first "New Town" located in Prussia the initiative of building a parish church in this shape belonged to Teutonics.

As M. Arszyński rightly claimed, it wasn't only the consequence of the Teutonic Order pa-

[w:] Visibilia et invisibilia w sztuce średniowiecza. Księga poświęcona pamięci profesor Kingi Szczepkowskiej-Naliwajek, red. A. BADACH, M. JANISZEWSKA, M. TARKOWSKA, Warszawa 2009, s. 141-158.

41 Południowo-zachodnioniemiecki rodowód był akcentowany głównie przez Clasena: Karl-Heinz CLASEN, Die mittelalterliche Bildhauerkunst im Deutschordensland Preussen. Die Bildwerke bis zur Mitte des 15. Jahrhunderts, Bd. 1, Berlin 1939, zwł. s. 50. Por. także: JURKLOWLANIEC 1989, s. 80. 
tronage but also - a result of the subordination of the municipal councils to the Teutonics knights (in the beginnings of the 14th century there weren't institutions so-called provisores and fabrica ecclesiae).

Concluding, the question what was really persuaded the Order to the realisation of such an effective architectural form just in the New Town of Torun - is still remaining opened. 


\section{SPIS ILUSTRACJI:}

1. Toruń, kościół pw. św. Jakuba, widok od północy, fot. A. Skowroński.

2. Toruń, kościół pw. św. Jakuba, wnętrze prezbiterium, fot. A. Skowroński.

3. Toruń, Kościół pw. św. Jana Chrzciciela i św. Jana Ewangelisty, wnętrze prezbiterium,fot. A. Skowroński.

4. Dawny ratusz Nowego Miasta Torunia, potem - kościół ewangelicki. Rycina Jerzego Fryderyka Steinera, 1 poł. XVIII wieku. Wg: Toruń i miasta ziemi chetmińskiej na rysunkach Jerzego Fryderyka Steinera z pierwszej połowy XVIII wieku (tzw. Album Steinera), red. M. BISKUP, Toruń 1998, s. 92.

5. Plan Nowego Miasta Elbląga, fragment z: Elbląg. Plan i widok miasta około 1642 r. Wg: Atlas historyczny miast polskich, Tom I, Prusy Królewskie i Warmia, red. A. CZACHAROWSKI, z.1: Elbląg, oprac. R. CZAJA, Z. KOZIEŁ, Toruń 1993, karta 9.

6. Widok Torunia od wschodu, litografia, Robert Assmus, Lipsk ok. 1860. Wg: Toruń. Alte Ansichten der Stadt. Eine Ausstellung des Bezirksmuseums Toruń, Städtisches Museum Göttingen, 25. Juli-22. August 1993, oprac. A. MIERZEJEWSKA, M. WOŹNIAK, Toruń 1993, il. 48.

7. Plan Nowego Miasta Torunia, wg: MIKULSKI 1999, s. 39. 


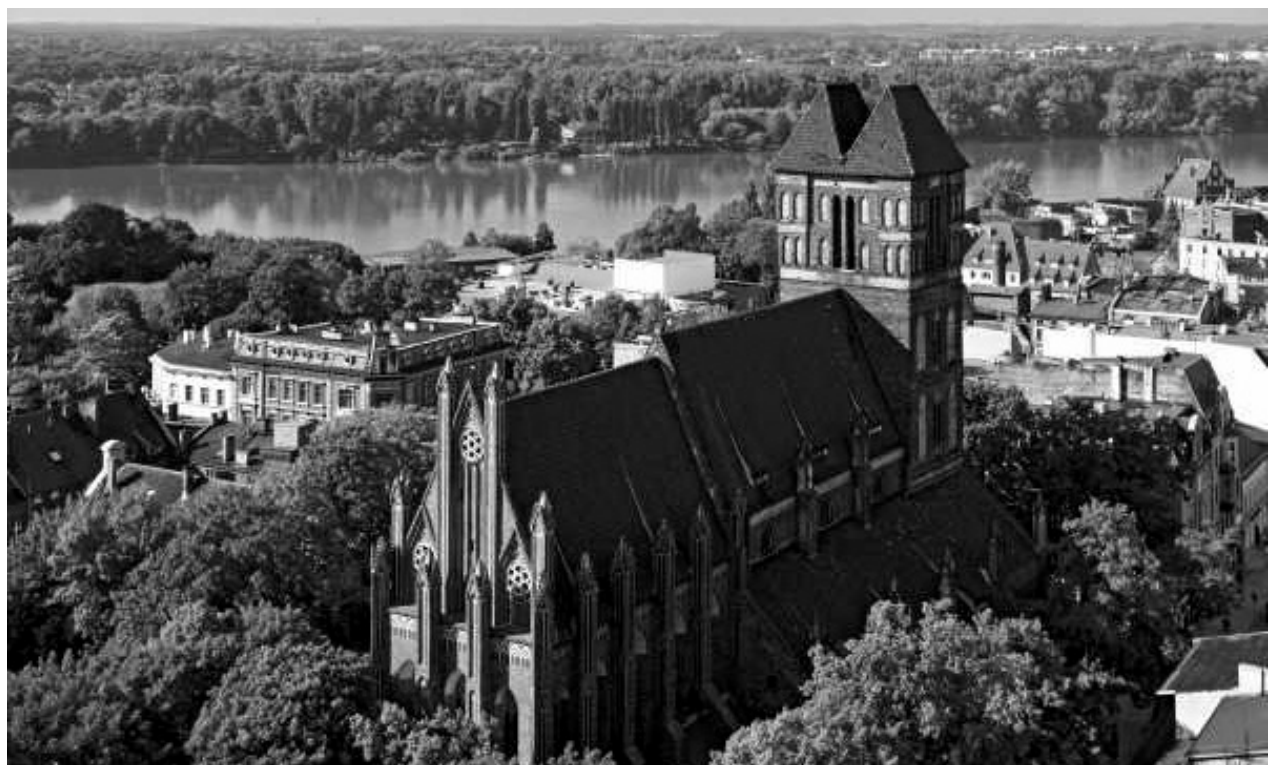

Il. 1 Toruń, kościół pw. św. Jakuba, widok od północy, fot. A. Skowroński

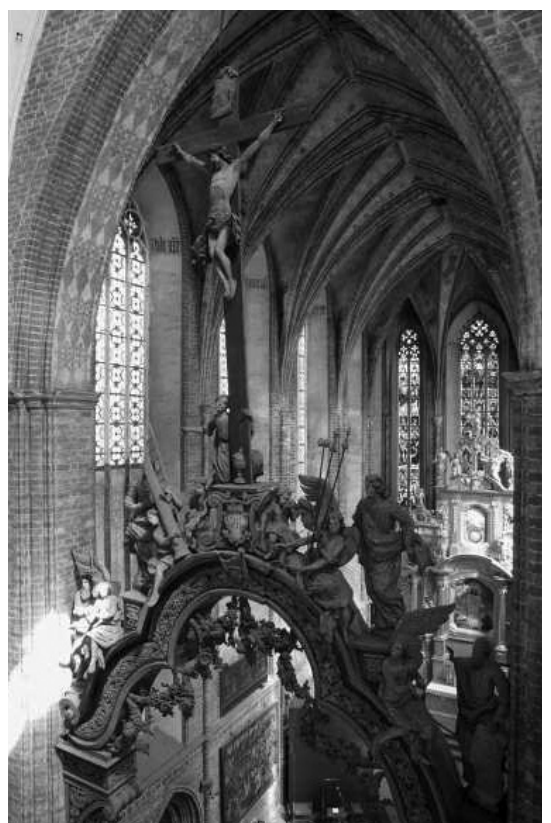

Il. 2 Toruń, kościół pw. św. Jakuba, wnętrze prezbiterium, fot. A. Skowroński

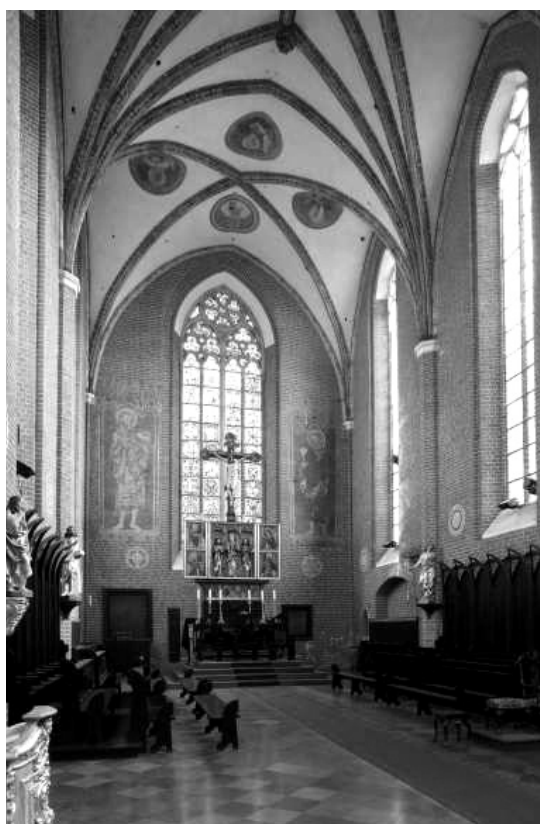

Il. 3 Toruń, Kościół pw. św. Jana Chrzciciela i św. Jana Ewangelisty, wnętrze prezbiterium, fot. A. Skowroński 


$$
\begin{aligned}
& \text { Perpectivifger L lave? }
\end{aligned}
$$

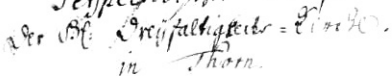

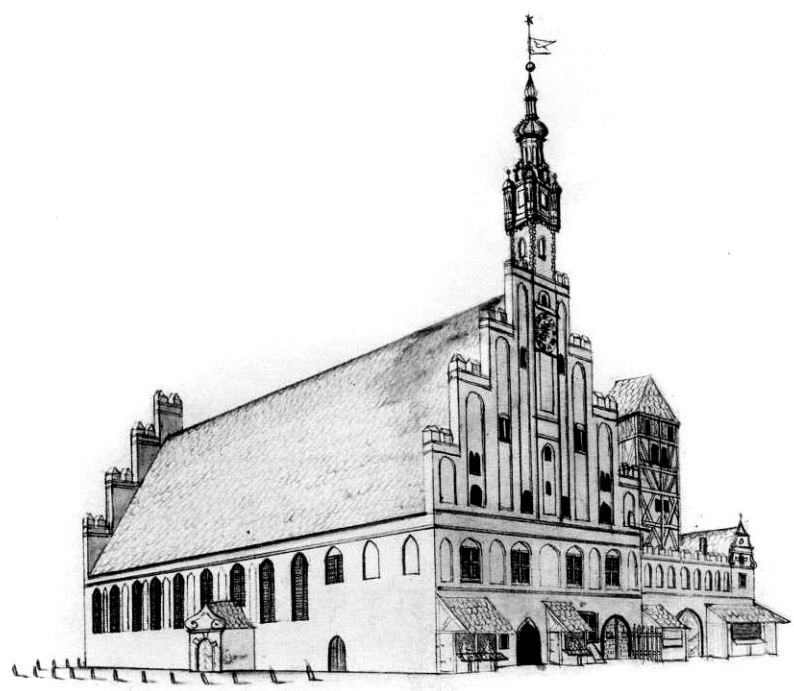

Il. 4 Dawny ratusz Nowego Miasta Torunia, potem - kościół ewangelicki. Rycina Jerzego Fryderyka Steinera, 1 poł. XVIII wieku. Wg: Toruń i miasta ziemi chełmińskiej na rysunkach Jerzego Fryderyka Steinera z pierwszej połowy XVIII wieku (tzw. Album Steinera), red. M. BISKUP, Toruń 1998, s. 92

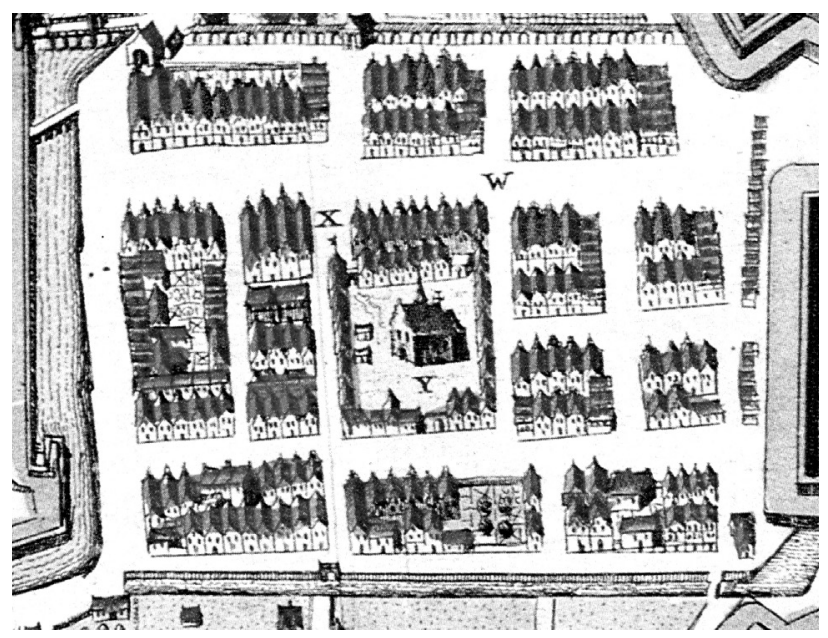

Il. 5 Plan Nowego Miasta Elbląga, fragment z: Elbląg. Plan i widok miasta około 1642 r. Wg: Atlas historyczny miast polskich, Tom I, Prusy Królewskie i Warmia, red. A. CZACHAROWSKI, z.1: Elbląg, oprac. R. CZAJA, Z. KOZIEŁ, Toruń 1993, karta 9 


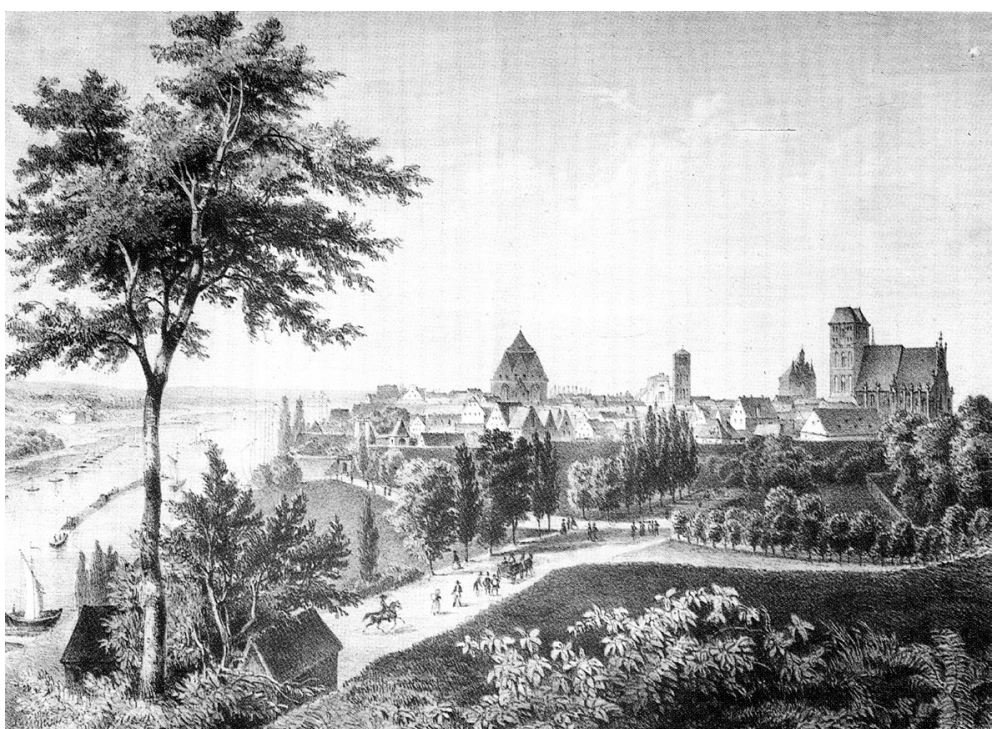

Il. 6 Widok Torunia od wschodu, litografia, Robert Assmus, Lipsk ok. 1860. Wg: Toruń. Alte Ansichten der Stadt. Eine Ausstellung des Bezirksmuseums Toruń, Städtisches Museum Göttingen, 25. Juli-22. August 1993, oprac. A. MIERZEJEWSKA, M. WOŹNIAK, Toruń 1993, il. 48

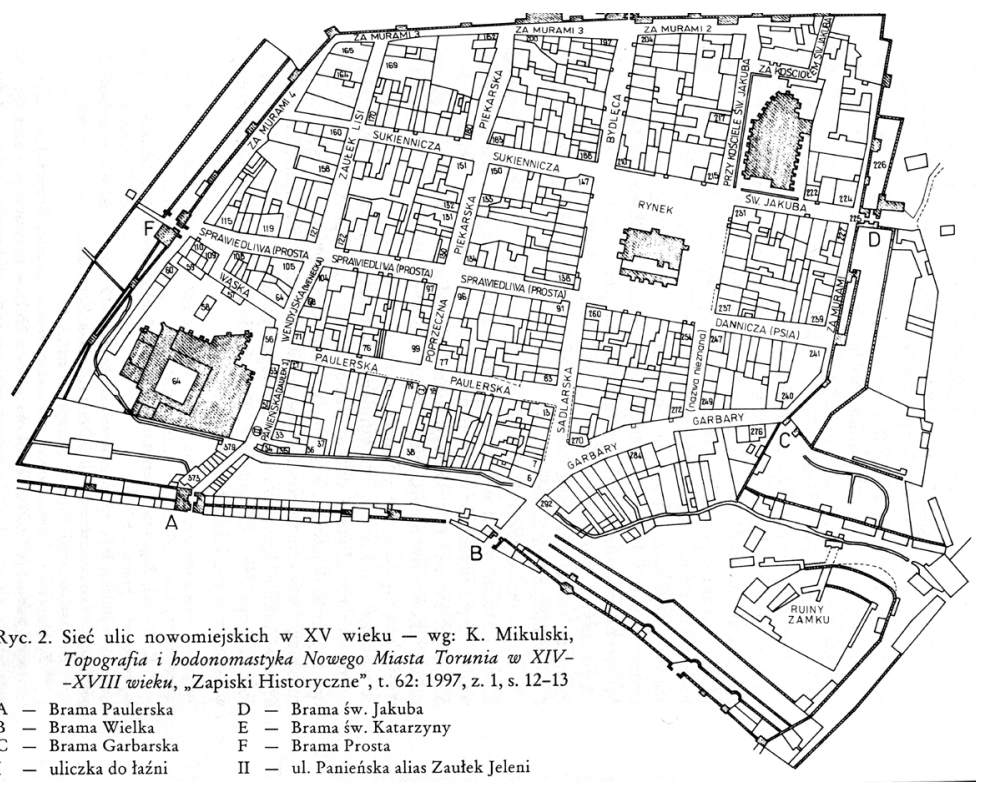

Il. 7 Plan Nowego Miasta Torunia, wg: MIKULSKI 1999, s. 39 